\title{
Rezime
}

Novčanica od 1.000 dinara koja nosi na sebi datum izdanja 1. decembar 1931. godine puštena je u opticaj 1. januara 1933. godine, a povučena iz opticaja u periodu od 4. do 11. juna 1941. godine. Snimanje i izrada klišea obavljeni su u Banque de France, u Parizu, hartija sa vodotiskom nabavljena je iz firme Portals Ltd, Hants, Engleska, a štampana je u Zavodu za izradu novčanica u Beogradu. Autor ove novčanice je Paja Jovanović, jedan od najvećih srpskih slikara. Nema zvaničnih podataka o visini tiraža novčanice, ali se na osnovu naručene količine hartije može pretpostaviti da je izrađeno od 10 do 11 miliona komada novčanica u nominalnoj vrednosti od 10 do 11 milijardi dinara. Dimenzije novčanice su 195x121mm, crteža 181x112mm i vodotiska u prečniku $35 \mathrm{~mm}$. Na novčanici dominira lik kraljice Marije Karađorđević, a na vodotisku je profil kralja Aleksandra Karađorđevića.

Ključne reči: novčanica, 1.000 dinara, kraljica Marija Karađorđević, kralj Aleksandar Karađorđević, Paja Jovanović, Narodna banka Kraljevine Jugoslavije, Banque de France, Zavod za izradu novčanica 


\section{WHAT MAKES \\ THE 1,000-DINAR \\ BANKNOTE OF THE \\ NATIONAL BANK \\ OF THE KINGDOM \\ OF YUGOSLAVIA \\ EXTRAORDINARY}

\section{Summary}

The 1,000-dinar banknote bearing the issuing date 1 December 1931 was put into circulation on 1 January 1933 and withdrawn from circulation in the period from 4-11 June 1941. The recording and production of the clichés were done at the Banque de France, Paris, while the watermarked paper was purchased from Portals Ltd, Hants, England and printed at the Institute for Manufacturing Banknotes and Coins in Belgrade. The author of this banknote is Paja Jovanović, one of the greatest Serbian painters. There is no official information on the exact number of these banknotes in circulation, but based on the amount of paper ordered, it can be assumed that 10 to 11 million banknotes were made in the nominal value of 10 to 11 billion dinars. Banknote dimensions are 195x121mm, drawing dimensions are $181 \times 112 \mathrm{~mm}$ and the watermark is $35 \mathrm{~mm}$ in diameter. The banknote is dominated by the image of Queen Marija Karađorđević, and the watermark shows the profile of King Aleksandar Karađorđević.

Keywords: banknote, 1,000 dinars, Queen Marija Karađorđević, King Aleksandar Karađorđević, Paja Jovanović, the National Bank of the Kingdom of Yugoslavia, Banque de France, The Institute for Manufacturing Banknotes and Coins 
$\mathrm{P}$ ostoji nekoliko ključnih podataka koji čine posebnom novčanicu od 1.000 dinara Narodne banke Kraljevine Jugoslavije sa datumom izdanja 1. decembar 1931. godine, puštenu u opticaj 1. januara 1933. godine:

- Njena godina izdanja je i godina kada se završava zakonska stabilizacija dinara i ustanovljenje njegovog zlatnog važenja;

- Ovo je prva novčanica u tečaju na kojoj je izostavljen deo klauzule o isplati „u metalnoj zakonskoj valuti", što je bio slučaj i kod svih drugih novčanica koje nose datum izdanja tridesetih godina prošlog veka;

- Prvi put od Kneževine Srbije do Kraljevine Jugoslavije na novčanici je prikazana stvarna, istorijski poznata ženska osoba u liku kraljice Marije Karađorđević;

- Izradu crteža za novčanicu Narodna banka je poverila Paji Jovanoviću, velikom srpskom slikaru;

- Najveći deo gotovinskog prometa $\mathrm{u}$ Kraljevini Jugoslaviji obavljao se ovom novčanicom.

\section{Stabilizacija dinara i tri važna zakona}

Ujunu 1931.godineozakonjenajestabilizacija dinara donošenjem tri važna zakona: Zakona o novcu Kraljevine Jugoslavije, Ugovora između države i Narodne banke za izvršenje Zakona o novcu Kraljevine Jugoslavije i Zakona o Narodnoj banci Kraljevine Jugoslavije. Naime, Zakon o novcu doneo je značajne promene $\mathrm{u}$ novčani sistem zemlje. Utvrđena je vrednost dinara od 0,0265 grama čistog zlata, tako da je kilogram zlata stajao $37.735,85$ dinara, što je odgovaralo paritetu od 9,12778 švajcarskih franaka za 100 dinara. Uvedena je zamenljivost domaćih novčanica za zlato u polugama i za devize koje su se mogle zameniti za zlato, ali ne za iznos manji od 250.000 dinara. Novčanice u opticaju i ostale obaveze Narodne banke po viđenju morale su imati 35\% pokriće, 25\% u zlatu, a ostatak u zlatnim devizama. Ovim zakonom je, po prvi put od stvaranja Kraljevine SHS 1918. godine, dinar označen kao novčana jedinica Kraljevine Jugoslavije.

Ugovor između države i Narodne banke za izvršenje Zakona o novcu Kraljevine Jugoslavije, odobren posebnim Zakonom, utvrdio je izvore sredstava i način za smanjenje zaduženja države kod Narodne banke. Do 28. juna 1931. godine dug države iznosio je preko 4,1 milijardu dinara, da bi se primenom Ugovora smanjio na oko 1,8 milijardi dinara. Sredstva za tu operaciju država je obezbedila:

- Devizama u vrednosti od 1,4 milijarde dinara iz prinosa "7\% državnog stabilizacionog zajma“ koji je zaključen sa jednim međunarodnim konzorcijumom banaka;

- Sredstvima od preko 0,9 milijardi dinara po osnovu revalorizacije podloge Narodne banke u zlatu i devizama na bazi novog pariteta dinara i obračunom vrednosti srebra po novoj ceni;

- Učešćem države u dobiti Narodne banke u toj godini, odnosno do 28. juna 1931. godine, kada je Zakon o novcu stupio na snagu.

Zakon o Narodnoj banci Kraljevine Jugoslavije donosi izmene i novine $\mathrm{u}$ odnosu na Zakon o Narodnoj banci iz 1920. godine. Njen prevashodni zadatak sada je staranje o stabilnosti i sigurnosti dinara, a kao drugi kreditiranje privrede. Glavnica Narodne banke povećana je od 30 na 180 miliona dinara sredstvima iz njenih fondova.

„Svi ovi propisi i mere koji su označili zakonsku stabilizaciju dinara doneti su, međutim, u neprikladno vreme. U svetu već vlada privredna kriza. Nemačke obaveze po osnovu reparacija i ratnog duga su zamrznute (Huverov moratorijum od 20. juna 1931. godine) što je za Jugoslaviju značilo godišnji gubitak u devizama od oko 450 miliona dinara. Velika Britanija napušta 21. septembra 1931. godine zlatno važenje, što je predstavljalo monetarni udar svetskih razmera. Novi liberalni devizni režim u zemlji dovodi do nekontrolisanog odliva deviza. Spoljnotrgovinska razmena Jugoslavije 1929. godine drastično pada na svega $61 \%$ od te razmene. U Austriji i Mađarskoj, velikim partnerima u razmeni dobara, blokiraju se potraživanja naših izvoznika. Takav odjek svetske privredne krize na prilike $\mathrm{u}$ zemlji uslovio je zavođenje određenih restrikcija u deviznoj i kreditnoj sferi. Na predlog Narodne banke, ministar finansija oktobra 1931. godine ponovo zavodi obavezu ustupanja deviznog priliva, i to $50 \%$ od izvoza i $100 \%$ deviznog priliva po drugim osnovama. Krajem 1931. godine deo obaveznog ustupanja deviza penje se na $80 \%$. Pošto je na 


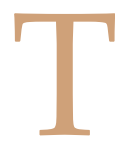
here are several key pieces of information that distinguish the 1,000-dinar banknote of the National Bank of the Kingdom of Yugoslavia, with the issue date of 1 December 1931, released into circulation on 1 January 1933 :

- Its year of issuing is also the year when the legal stabilisation of the dinar and the establishment of its golden validity were finalised;

- This is the first banknote in circulation that omits a part of the payment clause "in legal tender metal", which was the case with all other banknotes bearing the issue date of the 1930s;

- This is the first banknote depicting a real, historically known female figure - Queen Marija Karađorđević - that appeared in circulation from the time of the Principality of Serbia until the establishment of the Kingdom of Yugoslavia;

- The National Bank entrusted the drawing of the banknote to Paja Jovanović, a great Serbian painter;

- Most of the cash turnover in the Kingdom of Yugoslavia was made with this banknote.

\section{Stabilisation of the Dinar and Three Important Laws}

In June 1931, the stabilisation of the dinar was enacted by the adoption of three important laws: the Law on Money of the Kingdom of Yugoslavia, the Agreement between the State and the National Bank for the Implementation of the Law on Money of the Kingdom of Yugoslavia, and the Law on the National Bank of the Kingdom of Yugoslavia. Specifically, the Law on Money brought about significant changes in the country's monetary system. The value of the dinar was found to be 0.0265 grams of pure gold, so that a kilogram of gold stood at 37,735.85 dinars, which corresponded to a parity of 9.12778 Swiss francs per 100 dinars. Domestic banknotes could then be exchanged for gold in levers, and for foreign currencies that could also be exchanged for gold, but only in case of amounts higher than 250,000 dinars. Banknotes in circulation and other National Bank's liabilities on demand had to have 35\% coverage, with $25 \%$ coverage being in gold and the rest in gold foreign currencies. By this law, for the first time since the establishment of the Kingdom of Serbs, Croats and Slovenes, in 1918, the dinar was designated as a monetary unit of the Kingdom of Yugoslavia.

The Agreement between the State and the National Bank for the Implementation of the Law on Money of the Kingdom of Yugoslavia, approved by a special Law, determined the sources of funds and the way to reduce the state's debt to the National Bank. By 28 June 1931, the debt of the state amounted to over 4.1 billion dinars, only to be reduced to about 1.8 billion dinars by the implementation of the Agreement. The state provided the funds for this operation through the following means:

Foreign exchange worth 1.4 billion dinars from the yield of the " $7 \%$ government stabilisation loan" concluded with an international consortium of banks;

More than 0.9 billion dinars from the revaluation of the National Bank's base in gold and foreign currencies, based on the new dinar parity and the calculation of the value of silver at the new price;

State participation in the National Bank's profits in that year, i.e. until 28 June 1931, when the Law on Money came into force.

The Law on the National Bank of the Kingdom of Yugoslavia makes amendments to the Law on the National Bank from 1920. Its overriding task now is to maintain the stability and security of the dinar and, secondly, to lend to the economy. The principal of the National Bank was increased from 30 to 180 million dinars with the assets from its funds.

"However, all these regulations and measures that marked the legal stabilisation of the dinar were passed at an inappropriate time. There was already a global economic crisis happening. German reparations and war debt obligations were frozen (The Hoover Moratorium, 20 June 1931), which meant an annual foreign currency loss of about 450 million dinars for Yugoslavia. On 21 September 1931, the United Kingdom abandoned its golden value, which meant a world-wide monetary coup. The country's new liberal foreign exchange regime leads to an uncontrolled outflow of foreign exchange. The foreign trade of Yugoslavia in 1929 dropped dramatically to only $61 \%$ of that exchange. In Austria and Hungary, which were our strong partners in the exchange of goods, the claims of our exporters were being blocked. Such effect of 
stranim berzama velika špekulativna ponuda dinara, a potražnje nema, kurs dinara pada. U maju 1932. godine 100 dinara je vredelo 9 švajcarskih franaka, a u oktobru iste godine svega 6,60 švajcarskih franaka. Za podsticanje izvoza, krajem avgusta 1932. godine uvodi se „prim“ (dodatak) na zvanični kurs deviza. Prim se stalno povećava, pa je 3. marta 1933. godine iznosio već $28,5 \%$ za kliring, a $20 \%$ za ostale devizne transakcije. Sve te mere značile su samo jedno: napuštanje zlatnog važenja i poništavanje svih efekata stabilizacije dinara." (Novac Kraljevine Jugoslavije 1918-1941)

\section{Portret kraljice Marije Karađorđević}

Poznato je da su novčanice Kneževine Srbije, Kraljevine Srbije, Kraljevine SHS i Kraljevine Jugoslavije često imale prikaze vladara loze Karađorđević i Obrenović, a pojavljuju se i nepoznati likovi muškaraca, ali i istorijske ličnosti. Primera radi, to je slučaj sa novčanicom od 5 dinara Kraljevine Srbije sa različitim

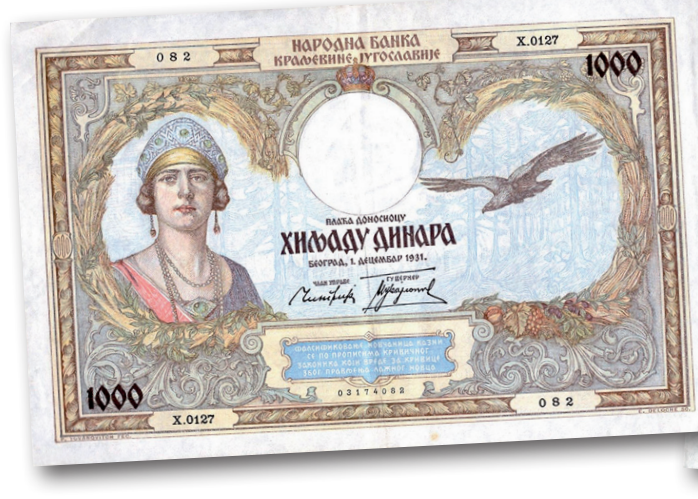

Novčanica od 1.000 dinara iz 1931. godine The 1,000-dinar banknote from 1931

datumima izdanja (1.9.1916 - 31.12.1917), sa kosovskim vojvodom Milošem Obilićem. Kada su ženski likovi u pitanju, interesantno je da su prikazane samo nepoznate ili imaginarne osobe. Jedina novčanica, i to u Kraljevini Jugoslaviji, koja nosi lik poznate, stvarne osobe, jeste ova od 1.000 dinara. Na njoj je dat portret kraljice Marije, supruge tadašnjeg kralja Jugoslavije, Aleksandra I Karađorđevića, čiji lik se takođe nalazi na ovoj novčanici, ali na vodotisku.

Ko je odlučio da se na ovoj novčanici, pored lika kralja Aleksandra, nađe i portret kraljice Marije nije poznato, ali se pouzdano zna da je
Narodna banka odlučila da izradu novčanice poveri našem tada najvećem i najpoznatijem slikaru Paji Jovanoviću. Bez obzira ko je idejni tvorac, odluka da Marija Karađorđević bude na novčanici sasvim je razumljiva, jer je ona bila poštovana kraljica koja je plenila skromnošću, humanošću, inteligencijom i posvećenošću poboljšanju životnih uslova stanovnika zemlje u koju je došla udajom. Posebno je bio izrazit njen rad na otvaranju novih škola, bolnica, poboljšanju životnih uslova dece bez roditelja i obrazovanju ženske dece.

Marija Karađorđević (Gota 9.1.1900 London 22.6.1961) je druga ćerka rumunskog kralja Ferdinanda Hoencolerna (1865-1927) i kraljice Marije (1875-1938). Potomak ruske kraljevske porodice i britanskog kraljevstva, rumunskoj kraljici baka po majci bila je velika knjeginja Marija Aleksandrova, sestra ruskog cara Aleksandra III, a deda po majci bio joj je Alfred, vojvoda od Edinburga, drugi sin britanske kraljice Viktorije. Za kralja Aleksandra Marija se udala 8.6.1922. godine, a venčanje je obavljeno u Sabornoj crkvi u Beogradu. Naš

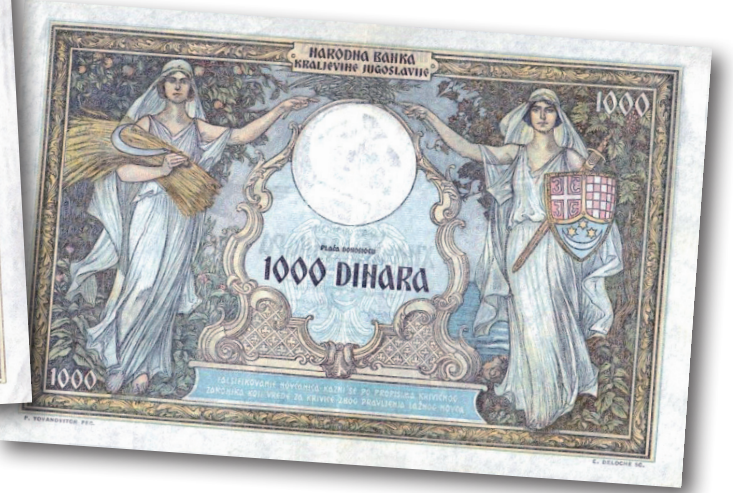

poznati komediograf i diplomata, Branislav Nušić, bio je zadužen za organizaciju ovog venčanja. Venčani kum im je bio engleski kralj Džordž V koga je zamenjivao sin, princ Albert. U braku su dobili tri sina: Petra (1923-1970), Tomislava (1928-2000) i Andreju (1929-1990). Nakon ubistva kralja Aleksandra, 9. oktobra 1934. godine u Marseju, odlazi iz zemlje i živi u seoskoj kući kraj Londona. Sahranjena je u Vindzoru, a tek 26. maja 2013. godine njeni zemni ostaci preneti su u crkvu Svetog Đorđa na Oplencu, Topola, gde se nalaze grobovi loze Karađorđevića i gde je sahranjen i njen suprug kralj Aleksandar. 
the world economic crisis on the conditions in the country led to the establishment of certain restrictions in the fields of foreign exchange and lending. At the proposal of the National Bank, in October 1931, the Minister of Finance reinstates the obligation to transfer foreign currency inflows, namely $50 \%$ of exports and $100 \%$ of foreign currency inflows on other grounds. At the end of 1931, the portion of the mandatory foreign currency transfer rises to $80 \%$. Since there is a large speculative supply of dinars on foreign stock exchanges and there is no demand, the dinar exchange rate falls. In May 1932, 100 dinars were worth 9 Swiss francs, and in October of the same year only 6.60 Swiss francs. In order to encourage exports, at the end of August 1932, an "addition" was introduced to the official exchange rate. This addition was constantly increasing, so on 3 March 1933 it was already at $28.5 \%$ for clearing and $20 \%$ for other foreign exchange transactions. All these measures meant only one thing: abandoning the golden value and cancelling all the effects of stabilising the dinar." (Novac Kraljevine Jugoslavije 1918-1941)

\section{The Portrait of Queen Marija Karađorđević}

It is known that the banknotes of the Principality of Serbia, the Kingdom of Serbia, the Kingdom of Serbs, Croats and Slovenes and the Kingdom of Yugoslavia often featured depictions of rulers from the Karađorđević and Obrenović dynasties, as well as images of unknown men and historical figures. For example, this is the case with the 5-dinar banknote of the Kingdom of Serbia with different issue dates (1.9.1916 31.12.1917) featuring the image of the Duke of Kosovo, Miloš Obilić. When it comes to female portraits, it is interesting that only unknown or imaginary characters were portrayed. The only banknote in the Kingdom of Yugoslavia, which bears the image of a famous, real person, is the 1000-dinar banknote. It depicts a portrait of Queen Marija, the wife of the then King of Yugoslavia, Aleksandar I Karađorđević, whose portrait is also featured on this banknote, but on the watermark.

It is unknown who decided to add the portrait of Queen Marija to this banknote, in addition to the image of King Aleksandar, but it is reliably known that the National Bank decided to entrust the making of the banknote to the then greatest and most famous painter in the country, Paja Jovanović. No matter who came up with the idea, the decision to feature Marija Karađorđević on the banknote is quite understandable, as she was a respected queen who exuded modesty, charity, intelligence and dedication to improving the living conditions of the people living in the country she married into. Her work on opening new schools and hospitals, improving the living conditions of children without parents, and educating girls was particularly prominent.

Marija Karađorđević (Gotha 9.1.1900 London 22.6.1961) was the second daughter of King Ferdinand I of Romania (1865-1927) and Queen Marie (1875-1938). A descendant of the Russian royal family and the British royalty, the Romanian Queen's maternal grandmother was Grand Duchess Maria Alexandrovna, sister of Russian Tsar Alexander III, and her maternal grandfather was Alfred, Duke of Edinburgh, second son of the British Queen Victoria. She married King Aleksandar on 8 June 1922, and the wedding took place at the Cathedral Church of St. Michael the Archangel in Belgrade. A famous Serbian comedian and diplomat, Branislav Nušić, was in charge of organising this wedding. The groomsman at their wedding was King George V of England, who was represented by his son, Prince Albert. Together they had three sons: Petar (1923-1970), Tomislav (1928-2000) and Andrej (1929-1990). After the assassination of King Aleksandar, on 9 March 1934, in Marseille, she departed the country and lived in a farmhouse near London. She was buried in Windsor, and it was not until 26 May 2013 that her earthly remains were transferred to St. George's Church in Oplenac, Topola, where the members of the Karađorđević dynasty are buried, including her husband, King Aleksandar.

\section{Paja Jovanović - Author of the Banknote}

The preparations for the production of a 1,000-dinar permanent second edition banknote began in 1928. Following a principled decision to issue a new banknote, the National Bank 


\section{Paja Jovanović autor novčanice}

U 1928. godini počele su pripreme za izradu novčanice od 1.000 dinara stalnog II izdanja. Narodna banka se nakon načelne odluke o izdavanju nove novčanice opredelila i za njenog budućeg autora. Izbor je pao na Paju Jovanovića, jednog od najvećih i najpriznatijih srpskih slikara. Paja Jovanović (Vršac 1859 - Beč 1957) slavu je stekao svojim slikama na kojima su prikazane scene iz istorije i života Srba, Crnogoraca, Hercegovaca i Arbanasa (Mačevanje, Guslar, Kićenje neveste, Ranjeni Crnogorac, Borba petlova) i portreti poznatih i nepoznatih osoba (Mihajlo Pupin, Živojin Mišić, kralj Petar II Karađorđević, kralj Aleksandar Karađorđević, Kraljica Marija Karađorđević, Vuk Karadžić, princeza Milica, kralj Nikola, Josip Broz Tito, gospođa Hadson, gospođa Štraus, gospođa Doblin, gospođa Šink, itd.). Izradio je i velike kompozicije iz nacionalne istorije: Seoba Srba, Krunisanje cara Dušana, Ženidba cara Dušana, Takovski ustanak. Bio je veliki putnik, obilazio je mnoge krajeve sveta i u mnogim stranim gradovima je živeo izvestan broj godina: Beč, Beograd, Pariz, London, Minhen i Budimpešta.

Studije na Bečkoj Akademiji umetnosti završava za tri godine 1880. Nastavlja dalje obrazovanje na specijalnom kursu za istorijsko slikarstvo koji završava 1883. godine. Svoje slike izlagao je u mnogobrojnim svetskim galerijama, a prodavao ih je preko najpoznatijih galerista u najvećim evropskim metropolama. Za života primio je brojne nagrade i priznanja, a veoma rano je postao član Srpskog učenog družtva i Srpske kraljevske akademije nauka. Sahranjen je na Novom groblju u Beogradu u Aleji zaslužnih građana.

\section{Kliše iz Francuske, papir iz Engleske, a štampa u Beogradu}

Može se pretpostaviti da su nadležni predstavnici Narodne banke koji su i odlučivali o izboru umetnika koji će dati likovno rešenje novčanice od 1.000 dinara imali prilike da vide portret kraljice Marije i portret kralja Aleksandra, te da je to bio jedan od osnovnih razloga za izbor Paje Jovanovića. Konačna odluka da on bude izabran usledila je tek nakon dostave skica za novčanicu Narodnoj banci. Pismom od 24. aprila 1929. godine Narodna banka naručuje Paji Jovanoviću detaljne crteže, a njihova revizija, koja se odnosila na izmene u nazivu Narodne banke, datumu i potpisima na novčanici, snimanje i izrada klišea obavljeni su u Banque de France, Pariz. Graver ove novčanice bio je E. Deloche, koji je to bio i za neke prethodne naše novčanice. O izradi klišea u Parizu Narodna banka je pismom obavestila Juraja Demetrovića, ministra trgovine i industrije, decembra 1929. godine.

U izveštaju Narodne banke za 1931. godinu navodi se da će nova hiljadarka početi da se izrađuje početkom marta 1932. godine, jer su svi pripremni radovi za izradu ove novčanice završeni. U obećanom terminu, Narodna banka se obraća Miloradu Đorđeviću, ministru finansija da, s obzirom na to da su završene pripreme za štampanje novčanice od 1.000 dinara, predloži donošenje specijalnog zakona za izdavanje ove novčanice, ili da o tome donese svoju odluku. Pre nego što je ministar Đorđević doneo 17. marta rešenje da štampanje novčanica može da počne, Izvršni komitet Narodne banke, na sednici održanoj 8. marta, odlučuje da se sa štampanjem krene već 9 . marta 1932. godine.

Firma Portals Ltd, Hants, England izabrana je kao najbolji ponuđač da izradi hartiju sa vodotiskom. Prva naručena količina hartije za izradu 5.280.000 komada novčanica bila je sredinom septembra 1931. godine, a druga za 5.820.000 komada bila je u januaru 1932. godine. Prva isporučena hartija stigla je u Beograd već sredinom februara 1932. godine. Jedan paket od 1.000 listova (šest novčanica na jednom listu) koštao je 8 šilinga i 4 penija. Štampanje novčanice realizovalo se $\mathrm{u}$ Zavodu za izradu novčanica u Beogradu koji je počeo sa radom 1930. godine.

Kako nema zvaničnih podataka o visini tiraža novčanice od 1.000 dinara, na osnovu naručene količine hartije može se pretpostaviti da je izrađeno od 10 do 11 miliona komada u nominalnoj vrednosti od 10 do 11 milijardi dinara. Tako na primer, pouzdano se zna da je krajem 1940. godine u opticaju ovih novčanica bilo u vrednosti od 8.811.562.000 dinara. Sem tiraža nepoznati su i podaci o ukupnim troškovima izrade ove hiljadarke. Naime, tih godina objavljivani su samo zbirni podaci 
also chose its future author. Their choice was Paja Jovanović, one of the greatest and most esteemed Serbian painters. Paja Jovanović (Vršac 1859 - Vienna 1957) gained fame with his paintings depicting scenes from the history and life of Serbs, Montenegrins, Herzegovinians and the Arbanasi people (The Fencing Lesson, Guslar, Decorating of the Bride, The Wounded Montenegrin, Cockfighting) and his portraits of celebrities and strangers (Mihajlo Pupin, Živojin Mišić, King Petar II Karađorđević, King Aleksandar Karađorđević, Queen Marija Karađorđević, Vuk Karadžić, Princess Milica, King Nikola, Josip Broz Tito, Mrs. Hudson, Mrs. Strauss, Mrs. Doblin, Mrs. Shink, etc.). He also produced great compositions based on national history: Migration of the Serbs, The Proclamation of Dušan's Law Codex, The Wedding of Emperor Stefan Dušan, Takovo Uprising. He was a great traveller, who visited many parts of the world and lived in many different cities for a number of years: Vienna, Belgrade, Paris, London, Munich and Budapest.

He completed his studies at the Vienna Academy of Arts after three years, in 1880. He continued his education with a special course in historical painting, ending in 1883 . He exhibited his paintings in numerous galleries around the world, selling them via the most famous galleries in the largest European capitals. During his lifetime he received numerous awards and recognitions, and very early on became a member of the Serbian Learned Society and the Serbian Royal Academy of Sciences. He was buried in the New Cemetery in Belgrade in the Alley of Distinguished Citizens.

\section{Cliché from France, Paper from England, and Printing in Belgrade}

It can be assumed that the competent representatives of the National Bank, who also decided on the choice of the artist who was to provide the artistic solution of the 1,000-dinar banknote, had the opportunity to see the portrait of Queen Marija and the portrait of King Aleksandar, and that this was one of the main reasons for choosing Paja Jovanović. The final decision to choose him came only after the draft banknote had been submitted to the National Bank. By letter dated 24 April 1929, the
National Bank ordered detailed drawings from Paja Jovanović, and their revisions concerning changes in the name of the National Bank, date and signatures on the banknote, as well as the production of clichés were carried out at the Banque de France, Paris. The engraver of this banknote was E. Deloche, who also engraved some of our previous banknotes. In December 1929, the National Bank sent a letter to Juraj Demetrović, the Minister of Commerce and Industry, notifying him about the drafting of the cliché in Paris.

The 1931 report of the National Bank stated that the production of the new 1,000-dinar banknote would commence as of March 1932, as all preparatory work for the making of this banknote had been completed. Within the promised deadline, the National Bank addressed Milorad Đorđević, the Minister of Finance, to propose the adoption of a special law for the issuance of this banknote, or to have him make a decision on the matter, since the preparations for the printing of the 1,000-dinar banknote had been completed. Before Minister Đorđević made the decision on 17 March that the printing of the banknotes could begin, the Executive Committee of the National Bank, at its meeting held on 8 March, decided to start printing as early as 9 March 1932.

The company Portals Ltd, Hants, England was selected as the best bidder to produce the watermarked paper. The first order of paper for making 5,280,000 banknotes was in midSeptember 1931, and the second order for making another 5,820,000 pieces was in January 1932. The first delivered order of paper arrived in Belgrade as early as mid-February 1932. One packet of 1,000 sheets (six banknotes on one sheet) cost 8 shillings and 4 pennies. The printing of the banknote was carried out at the Institute for Manufacturing Banknotes and Coins in Belgrade, which began its operations in 1930.

As there are no official data on the amount of 1,000-dinar banknotes in circulation, based on the ordered quantity of paper, it can be assumed that 10 to 11 million banknotes were made in the nominal value of 10 to 11 billion dinars. For example, it is known for certain that at the end of 1940, a total 8,811,562,000 dinars' worth of these banknotes were in circulation. In addition to the information about the amount 
troškova za sve novčanice.

Novčanica od 1.000 dinara stalnog II izdanja puštena je u opticaj 1. januara 1933. godine, a povučena u periodu od 4. do 11. juna 1941. godine. Na početku Drugog svetskog rata $\mathrm{u}$ okupiranoj Srbiji zamenjena je novčanicom Srpske narodne banke.

Najveći deo gotovinskog prometa $u$ Kraljevini Jugoslaviji obavljao se ovom novčanicom od 1.000 dinara. Dok je bila u opticaju, prema podacima Banknotnog odeljenja Narodne banke, otkriveno je ukupno 17 falsifikata, tri prilično uspela i 14 veoma neuspešnih.

\section{Osnovne karakteristike novčanice}

Dimenzije novčanice od 1.000 dinara su $195 \times 121 \mathrm{~mm}$, crteža $181 \times 112 \mathrm{~mm}$, dok je vodotisak u prečniku 35mm. Hartija je bela, oslikana u više boja.

\section{Lice novčanice}

Lice novčanice je bogato ornamentima, na levoj strani nalazi se lik kraljice Marije, na sredini gornjeg dela je vodotisak sa levim profilom kralja Aleksandra Karađorđevića, a na desnoj crtež orla u letu. Tekst je štampan ćirilicom, slovima tipa iz Miroslavljevog jevanđelja. Iznad vodotiska je oštampano: NARODNA BANKA KRALJEVINE JUGOSLAVIJE a ispod vodotiska: plaća donosiocu HILJADU DINARA. Ispod toga piše: Beograd, 1. decembar 1931, sa leve strane je potpis Čingrije, člana Uprave a sa desne guvernera i Bajlonija i na kraju, na plavom uokvirenom polju, štampana je klauzula o kažnjavanju falsifikata.

Krupna brojka 1.000 nalazi se na gornjem levom i donjem desnom uglu crteža, a sitne brojke nalaze se i na bočnim stranama okvira. Oznaka serije je na gornjem desnom i donjem levom delu okvira novčanice, broj novčanice je na gornjem desnom i donjem levom delu okvira, kontrolni broj je ispod klauzule o kažnjivosti falsifikata. Francuskom ortografijom u donjem delu rama levo je dato prvo slovo imena i puno prezime autora crteža, a na desnoj strani prvo slovo i prezime gravera.

\section{Naličje novčanice}

Na levoj strani je žena koja drži snop žita i srp, a na desnoj žena koja nosi mač i štit sa državnim grbom. Kompletan tekst dat je latinicom: Narodna banka Kraljevine Jugoslavije, plaća donosiocu 1.000 dinara i klauzula o kažnjavanju falsifikatora. Oznaka nominalne vrednosti „1000“ nalazi se u gornjem desnom i donjem levom uglu crteža. Kao i na licu novčanice, data su i imena autora crteža i gravera. 
of banknotes in circulation, the information on the total cost of making these banknotes is also unknown. Namely, at the time only the aggregate cost data for all banknotes were published.

The 1,000-dinar permanent $2^{\text {nd }}$ edition banknote was put into circulation on 1 January 1933 and withdrawn from 4 to 11 June 1941. At the beginning of World War II in occupied Serbia, it was replaced by a banknote of the Serbian National Bank.

The largest share of the cash turnover in the Kingdom of Yugoslavia was carried out with this 1,000-dinar banknote. While in circulation, a total of 17 counterfeits were discovered, according to the National Bank's Banknote Department, three of which were quite successful and 14 quite unsuccessful.

\section{Basic Characteristics of the Banknote}

The dimensions of the 1,000-dinar banknote are $195 \times 121 \mathrm{~mm}$, the drawings are $181 \times 112 \mathrm{~mm}$, while the watermark is $35 \mathrm{~mm}$ in diameter. The paper is white, painted in multiple colours.

\section{The Obverse of the Banknote}

The obverse of the banknote is rich in ornaments, on the left side is the portrait of Queen Marija, in the middle of the upper part is a watermark with the left profile of King Aleksandar Karađorđević, and on the right is a drawing of an eagle in flight. The text is printed in Cyrillic, with type letters from Miroslav's Gospel. The following is printed above the watermark: NATIONAL BANK
OF THE KINGDOM OF YUGOSLAVIA and below the watermark: it pays the bringer ONE THOUSAND DINARS. Below it reads: Belgrade, 1 December 1931, on the left is the signature of Čingrija, a member of the Management Board and on the right is the signature of the Governor and Bajloni, and finally, in the blue framed box, a clause regarding the punishment of counterfeiters was printed.

The large number 1000 is featured on the upper left and bottom right corners of the drawing and small numbers are featured on the sides of the frame. The batch mark is located on the upper right and lower left of the banknote frame, the banknote number is on the upper right and lower left of the box, the control number is below the counterfeit penalty clause. The first letter of the name and full surname of the author of the drawing is given in French orthography in the lower part of the frame on the left, and the first letter of the name and full surname of the engraver is featured on the right side of the frame.

\section{The Reverse of the Banknote}

On the left is a woman holding a bundle of grain and a sickle and on the right is a woman brandishing a sword and shield with the state coat of arms. The full text is in Latin script: the National Bank of the Kingdom of Yugoslavia, pays the bringer 1,000 dinars and a clause regarding the punishment of counterfeiters. The nominal value of " 1,000 " is featured in the upper right and lower left corners of the drawing. As well as on the obverse the reverse also features the names of the author of the drawings and the engraver. 


\section{Juraj Demetrović \\ (Jastrebarsko, 1885 - Beograd, 1945)}

17 ao gimnazijalac u Zagrebu Juraj Demetrović je isključen iz svih škola u Hrvatskoj i Slavoniji zbog osnivanja, uređenja i pisanja u listu Naša snaga koji je bio promoter socijaldemokratskog pokreta. Maturirao je 1905. godine u Bjelovaru. Od 1907. godine gradi karijeru kao novinar i urednik u brojnim glasilima u Hrvatskoj. Postaje član socijaldemokratske stranke. Učesnik je brojnih konferencija poput onih u Ljubljani i Beogradu koje su okupljale Jugoslovenske i Balkanske socijaliste. Tvorac je Ljubljanske deklaracije gde je zastupao ideologiju jedinstvene Jugoslovenske nacije. Nakon atentata 1914. godine u Sarajevu na nadvojvodu Franca Ferdinanda i njegovu suprugu Sofiju, Demetrović je mobilisan, da bi iz vojske bio pušten 1917. godine.

U Kraljevini Srba, Hrvata i Slovenaca 1919. godine postaje poverenik za gospodarstvo u pokrajinskoj vladi za Hrvatsku i Slavoniju. Od 1923. do 1925. je na funkciji Kraljevskog namesnika za Hrvatsku i Slavoniju. U vladu generala Petra Živkovića ulazi 1929. godine. Od 1929. do 1931. godine ministar je trgovine i industrije a od 1932. do 1934. godine ministar poljoprivrede. Ministar trgovine i industrije ponovo postaje 1934. godine. Kao ministar, Demetrović je napisao brojne članke koji su se odnosili na aktuelna privredna i društvena pitanja. Aktivno je učestvovao u stvaranju Jugoslovenske nacionalne stranke i u njoj je ostao sve do 1938. godine. Za vreme II svetskog rata ziveo je u Beogradu i sarađivao sa okupatorima zbog čega je posle rata streljan.

\section{娄 \\ Juraj Demetrović \\ (Jastrebarsko, 1885 - Belgrade, 1945)}

s a high school student in Zagreb, Juraj Demetrović was expelled from all schools in Croatia and

Slavonia due to his founding, editing and writing in Naša snaga newspapers, which promoted the social democratic movement. He graduated in 1905 in Bjelovar. From 1907 onwards he built his career as a journalist and editor in numerous newsletters in Croatia. He became a member of the Social Democratic Party. He participated in numerous conferences such as those in Ljubljana and Belgrade that brought together Yugoslav and Balkan socialists. He is the creator of the Ljubljana Declaration, where he advocated the ideology of a unified Yugoslav nation. Following the assassination of Archduke Franz Ferdinand and his wife Sofia in 1914 in Sarajevo, Demetrović was mobilised, and later released from the army in 1917.

In 1919, in the Kingdom of Serbs, Croats and Slovenes, he became Commissioner for Economy in the Provincial Government for Croatia and Slavonia. From 1923 to 1925 he served as the Royal Deputy for Croatia and Slavonia. He joined General Petar Živković's government in 1929. From 1929 to 1931 he was Minister of Trade and Industry and from 1932 to 1934 he was Minister of Agriculture. He was again appointed Minister of Trade and Industry in 1934. As minister, Demetrović wrote numerous articles that deal with contemporary economic and social issues. He actively participated in the creation of the Yugoslav National Party and remained in it until 1938. During World War II he lived in Belgrade and cooperated with the occupying forces, which is why he was sentenced to be shot after the war. 


\section{Milorad Đorđević \\ (Šabac, 1896 - Beograd, 1943)}

Z

a vreme Prvog svetskog rata Milorad Đorđević je studije završio u Alžiru, gde je i doktorirao 1919. godine na temu Agrarni krediti u Jugoslaviji. U Ministarstvu finansija radio je od 1919. do 1931. godine kada je postao viceguverner Narodne banke Kraljevine Jugoslavije. Bio je ministar finansija od 19.11.1931. do 20.12.1934. godine. Aktivno je učestvovao u zaključivanju stabilizacionog zajma, kao i u izradi zakona o stabilizaciji dinara i zakona i statuta o Narodnoj banci. Potpredsednik Udruženja banaka postaje 1937. godine, u vreme velikih turbulencija u ovoj bankarskoj instituciji. Tada je ova važna ekonomska institucija, zahvaljujući učešću izuzetno politički i finansijski jake srpske elite u njenom radu, među kojima je bio i Đorđević, uspela da prevaziđe krizu i nastavi svoj uspešan rad sve do početka II svetskog rata.

\section{a将 \\ Milorad Đorđević \\ (Šabac, 1896 - Belgrade, 1943)}

(D) uring the World War I, Milorad Đorđević completed his studies in Algeria, where he obtained his doctorate in 1919 on agricultural loans in Yugoslavia. He worked at the Ministry of Finance from 1919 to 1931 when he became Vice Governor of the National Bank of the Kingdom of Yugoslavia. He was Minister of Finance from 19.11.1931 until 20.12.1934. He actively participated in the conclusion of the stabilisation loan, as well as in the drafting of the Law on the Stabilisation of the Dinar and the Statute and Law on the National Bank. He became Vice President of the Association of Banks in 1937, at a time of great turbulence in this banking institution. At that time, this important economic institution was able to overcome the crisis and continue its successful operations until the beginning of World War II, thanks to the participation of the extremely politically and financially strong Serbian elite in its operations, including Đorđević.

\section{Literatura / References}

1. Aleksić V. (2011), Udruženje banaka Beograd i srpska politička elita između dva svetska rata. Bankarstvo 5/6, Udruženje banaka Srbije, Beograd

2. Dugalić V., Mitrović A., Gnjatović D., Hofman G., Kovačević I., (2004), Narodna banka 1884 - 2004, Jugoslovenski pregled, Beograd

3. Hadži-Pešić (1995), Novac kraljevine Jugoslavije 1918 - 1941. Narodna banka Jugoslavije, Beograd

4. Matić V. (2014), Finansije srpske - Serbian Finances. Udruženje banaka Srbije, Beograd

5. Narodna banka 1884-1934. Zavod za izradu novčanica Topčider

6. Stojanović, Z. (2018), Mlin Bajloni - gorostas Stiške ravnice, Biblioteka Srboljub Mitić, Malo Crniće, dostupno na: http://www. bsmmc.rs/mlin-bajloni-gorostas-stiskeravnice/?lang=lat
7. Stojanović Ž. (2004), Novčanice Narodne banke 1884-2004. Jugoslovenski pregled, Beograd

8. Ćorović V. (1989), Istorija Srba, treći deo, Beogradski izdavačko-grafički zavod

9. Trpimir M. (ed.) (1993) Hrvatski biografski leksikon, Demetrović, Juraj Leksikografski zavod Miroslav Krleža, dostupno na: www. enciklopedija.lzmk.hr

10. Paja Jovanović, Biografija preuzeta sa: https:// www.biografija.org/slikarstvo/paja-jovanovic/

11. Paja Jovanović - srednje škole, preuzeto sa: www.srednjeskole.edukacija

12. Paja Jovanović, preuzeto sa: www. muzejvrsac.org.rs

13. Kraljica Marija, preuzeto sa: www. oskraljicamarija.edu.rs

14. Povratak kraljice Marije, Aleksandre i kraljevića Andreja preuzeto sa: www.vreme.com

15. Jedna Marijina rečenica bila je dovoljna da osvoji kralja Aleksandra, preuzeto sa: www.zena.blic.rs 